\title{
Biology and Management of Tasselflower (Emilia spp.) in Ornamental Crop Production'
}

\author{
Yuvraj Khamare, Chris Marble, Shawn Steed, and Nathan Boyd ${ }^{2}$
}

\section{Introduction}

The name tasselflower refers to two similar and closely related species of genus Emilia, Emilia sonchifolia (red tasselflower or lilac tasselflower) and Emilia fosbergii (Florida tasselflower). Both species are very similar in appearance but can be distinguished by small differences in their leaves and flower structures. These species are very common in Florida nurseries, greenhouses, and landscapes. This article was developed to help nursery growers, landscape professionals, and the general public identify tasselflower species, understand their biology, and provide information on ways to manage this weed.

\section{Species Description}

\section{Class}

Dicotyledonous plant

\section{Family}

Asteraceae

\section{Other Common Names}

Both species are commonly refered to as tasselflower. Other common names include red tasselflower, lilac tasselflower, Florida tasselflower, consumption weed, cupid's paintbrush, cupid's shaving brush, Flora's paintbrush, and purple sow thistle.

\section{Life Span}

Both species are annual herbs.

\section{Habitat}

Tasselflowers are fast-growing weeds and thrive under a wide range of conditions. They can grow in most soil types and may be found growing in full sun or partly shaded conditions. Both species are commonly found in nurseries, greenhouses, disturbed areas, gardens, abandoned farmland, forest edges, pastures, roadsides, and riverbanks (Figure 1).

1. This document is ENH1342, one of a series of the UF/IFAS Environmental Horticulture Department, UF/IFAS Extension. Original publication date June 2021. Visit the EDIS website at https://edis.ifas.ufl.edu for the currently supported version of this publication.

2. Yuvraj Khamare, graduate research assistant; Chris Marble, assistant professor, Environmental Horticulture Department, UF/IFAS Mid-Florida Research and Education Center, Apopka, FL; Shawn Steed, multicounty environmental horticultural Extension agent III, Seffner, FL; and Nathan Boyd, associate professor, Horticultural Sciences Department, UF/IFAS Gulf Coast Research and Education Center, Balm, FL.

The use of trade names in this publication is solely for the purpose of providing specific information. UF/IFAS does not guarantee or warranty the products named, and references to them in this publication do not signify our approval to the exclusion of other products of suitable composition.

Use pesticides safely. Read and follow directions on the manufacturer's label.

The Institute of Food and Agricultural Sciences (IFAS) is an Equal Opportunity Institution authorized to provide research, educational information and other services only to individuals and institutions that function with non-discrimination with respect to race, creed, color, religion, age, disability, sex, sexual orientation, marital status, national origin, political opinions or affiliations. For more information on obtaining other UF/IFAS Extension publications, contact your county's UF/IFAS Extension office. U.S. Department of Agriculture, UF/IFAS Extension Service, University of Florida, IFAS, Florida A \& M University Cooperative Extension Program, and Boards of County Commissioners Cooperating. Nick T. Place, dean for UF/IFAS Extension. 


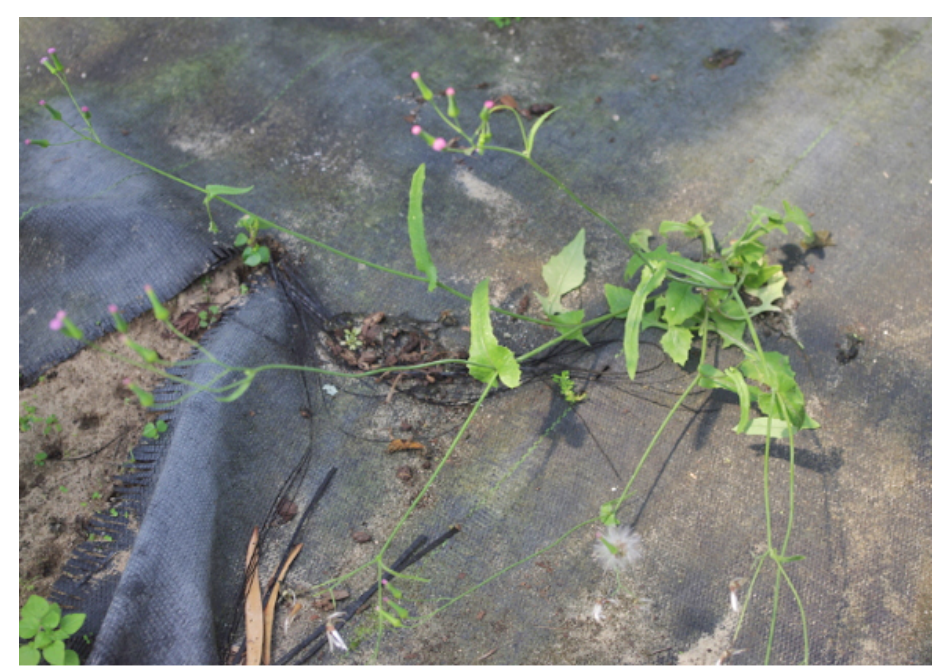

Figure 1. Emilia sonchifolia plant growing through a nursery weed mat. Credits: Annette Chandler, UF/IFAS

\section{Distribution}

E. sonchifolia is native to India, China, and Southeast Asia. It has widely spread and naturalized in North America, South America, Africa, and other tropical regions (USDAARS 2014b). The origin of E. fosbergii is uncertain, but it has been believed to originate from Africa or Asia. It is found in almost all the warm regions of the world (USDAARS 2014a). Both the species are nonnative to Florida and can be seen growing throughout the year and throughout the entire state, but they are most commonly found in central and south Florida (Wunderlin 2020).

\section{Growth Habit}

Both species are annual herbs that grow upright (erect) and have multiple branches reaching 8 to over 24 inches in height. The growth habit of both species is classified as a basal rosette of leaves and then has upright stems (Neal and Derr 2005).

\section{Seedling}

In Florida, germination can occur at any time throughout the year when temperatures are above $70^{\circ} \mathrm{F}$ and soil is not excessively dry (Lessa et al. 2013) (Figure 2). During their juvenile stage, the leaves grow in a circular arrangement (rosette), and then stems elongate. The stems on young plants are hairy but tend to lose hair as they age.

\section{Shoot}

The stems of both species are smooth or sparsely hairy (pubescent) with soft and slender purplish-green branches (Figures 3 and 4). The leaves are arranged alternately in both species. In E. sonchifolia the lower leaves are round and kidney-shaped or triangular-ovate (egg-like) with narrowly winged petioles (stem-like leaf attachments), while the upper leaves are lanceolate (narrow oval shape tapering to a point) with their bases encircling the stem (Figure 4). The lower leaves grow 1.5 to 6 inches long and 0.3 to 3 inches wide. The leaves of $E$. fosbergii are fiddle-shaped, ovate to oblanceolate (narrow to oval-shaped), often tapering to a winged petiole. The leaf margins are slightly serrated (toothed), 2 to 4 inches long, and 0.7 to 2 inches wide. In both species, the leaves are dark green on the top surface and lighter green underneath, and more or less irregularly coarsely toothed. The leaves on the upper stems are usually smaller than the leaves on the lower stems.

\section{Roots}

Both species have a branched taproot system.

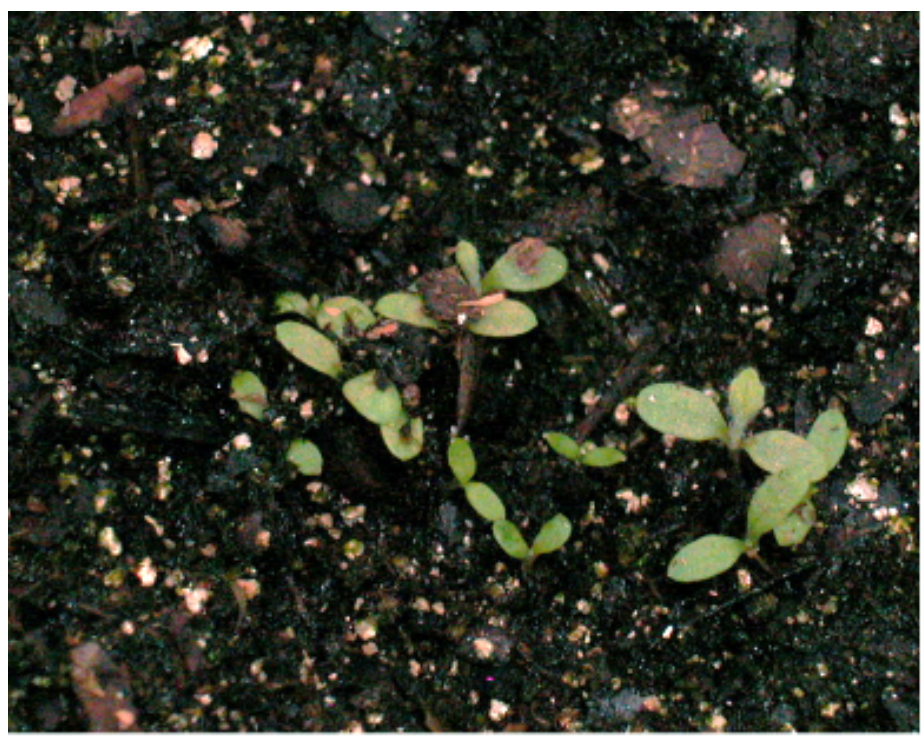

Figure 2. Emilia sonchifolia seedling.

Credits: Annette Chandler, UF/IFAS

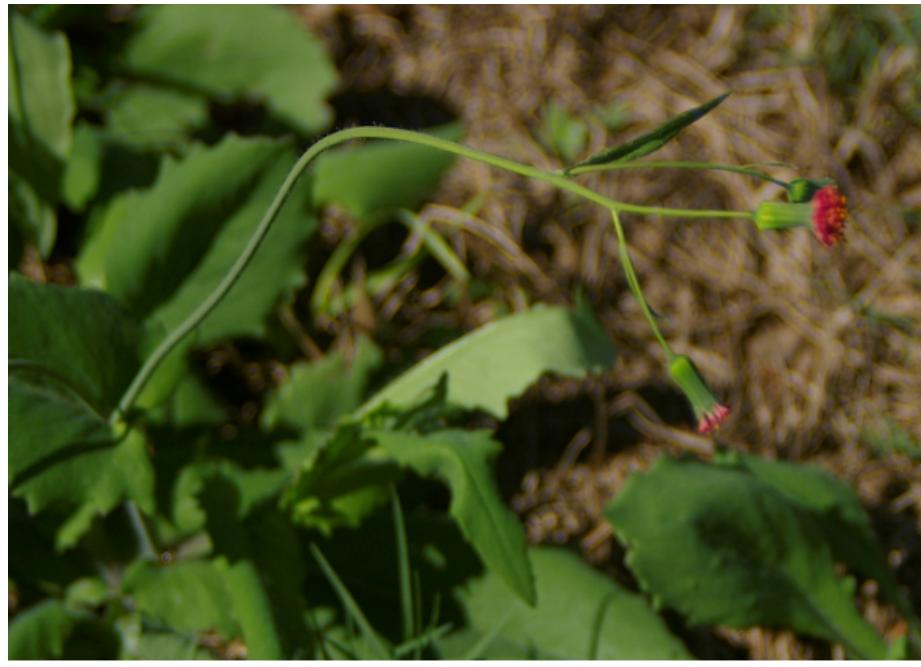

Figure 3. Emilia fosbergii stem.

Credits: Annette Chandler, UF/IFAS 


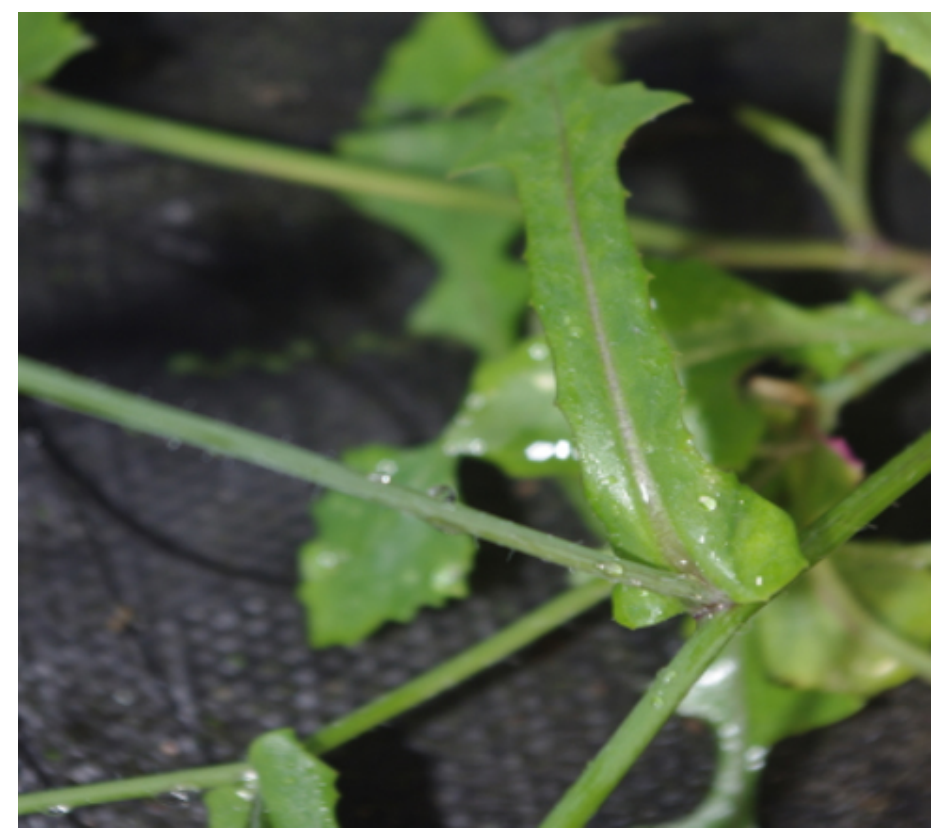

Figure 4. Emilia sonchifolia stem and leaves.

Credits: Annette Chandler, UF/IFAS

\section{Inflorescence}

The inflorescence or flower in E. sonchifolia is terminal and flat-topped with 3-6 stalked flower heads. The flower head is urn-shaped and consists of 30-60 florets per head. It is 0.4 to 0.5 inches long and 0.1 to 0.2 inches wide. The flowers range between orange, purple, pink, and white in color (Figure 5).

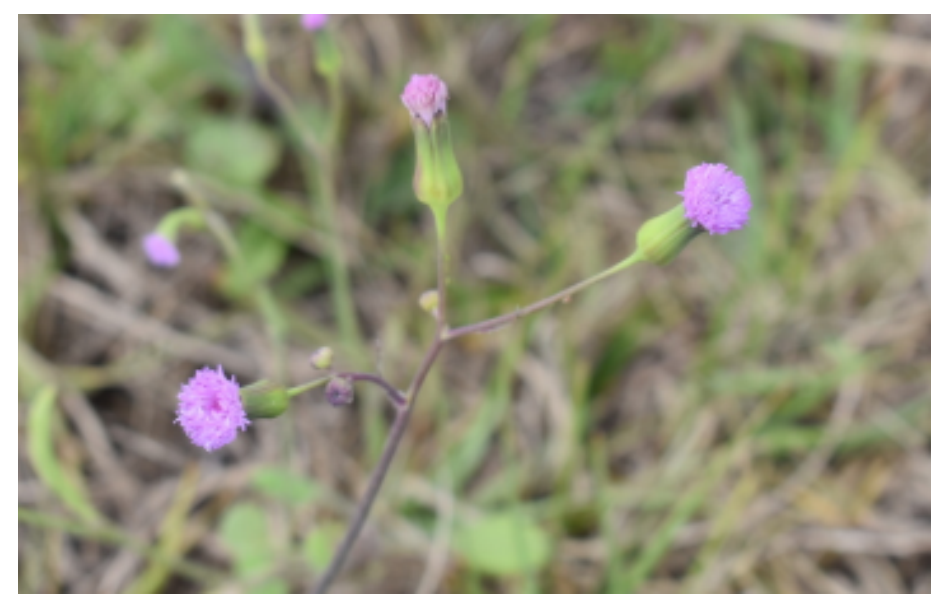

Figure 5. Emilia sonchifolia flowers.

Credits: Annette Chandler, UF/IFAS

E. fosbergii has one to several loose heads. The inflorescence is terminally or laterally in the axils of upper stems. The flower head is bell-shaped and consists of 15-30 florets per head. The color of the flower ranges between pink, light purple, and red (Figure 6). E. fosbergii does not have ray florets.

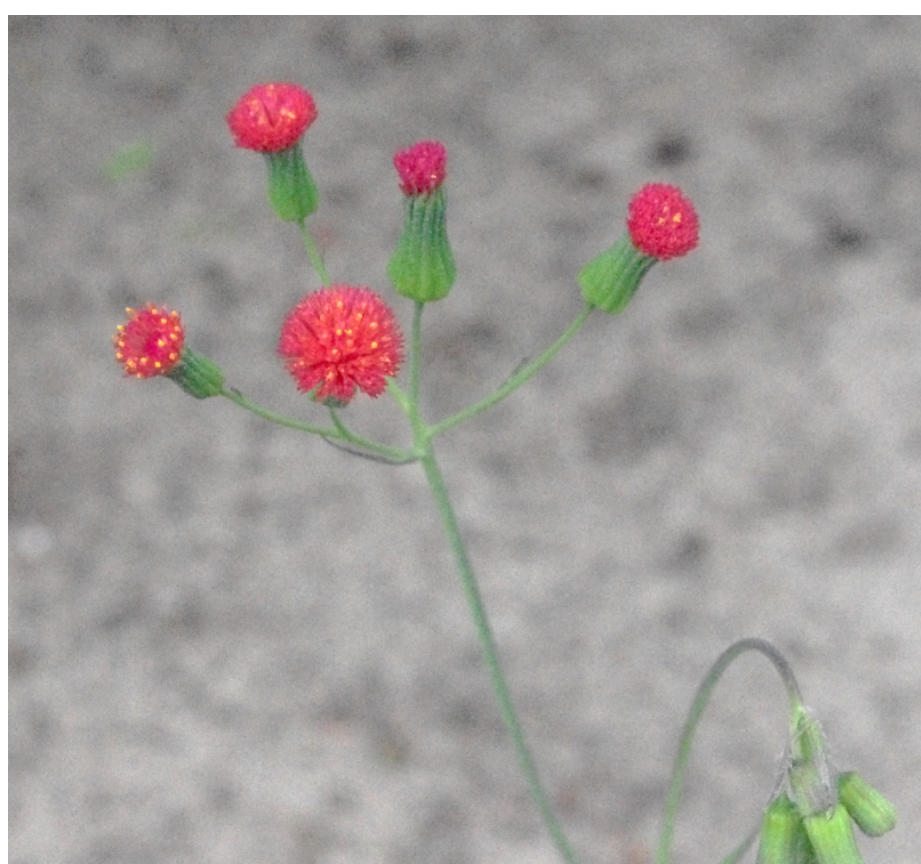

Figure 6. Emilia fosbergii flowers.

Credits: Annette Chandler, UF/IFAS

\section{Fruit and Seeds}

The fruit in both species is a dry achene (hard fruit), reddish brown to off-white in color, and approximately 0.2 inches long. The fruit has a pappus of abundant white hairs, which are up to 0.3 inches long (Figure 7). The pappus of white hairs helps to disperse the seed in the wind.

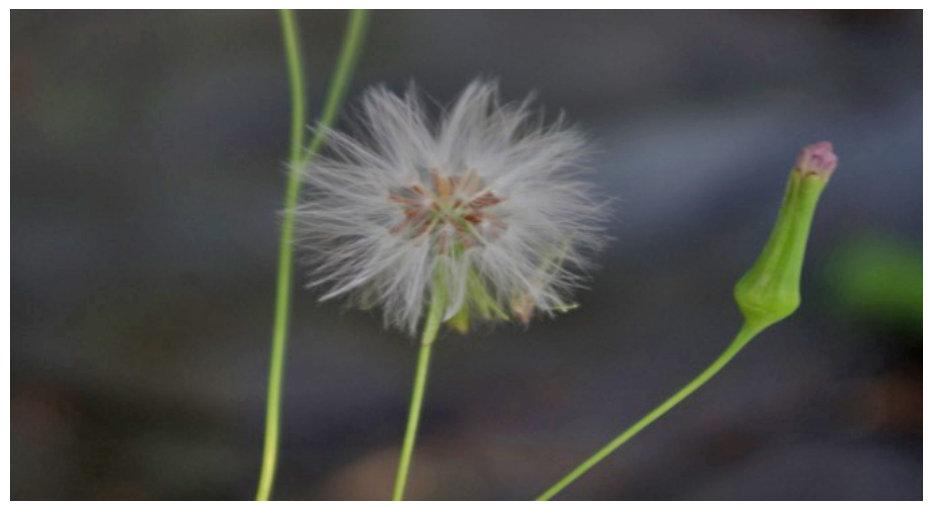

Figure 7. Emilia sonchifolia seeds.

Credits: Annette Chandler, UF/IFAS

\section{Similar Species}

The genus Emilia comprises approximately 100 species distributed in tropical regions. Emilia sonchifolia, Emilia fosbergii, and Emilia coccinea are three closely related and very similar species in terms of their appearance and biology. They can be distinguished by their color and shape of leaves (CABI 2019a, b). E. coccinea has bright orange to red-colored flowers, and its leaves are not feather-shaped like the other two Emilia species. E. coccinea has not been documented in Florida (Wunderlin et al. 2020). 


\section{Plant Biology}

Both species are fast growing and are capable of producing more than 5,000 seeds per plant in as few as 8 weeks after germination (CABI 2019a, b). They mostly bloom yearround but more frequently from late summer or early fall until spring (August to April) in Florida. Most of the seeds germinate at or near surface with a temperature above $70^{\circ} \mathrm{F}$. They grow best in full sunlight and complete their life cycle in about 90 days. The plants are known to attract bees and butterflies (Figure 8) but are mostly pollinated by wind. Both species spread predominately by seed, which is easily spread by wind.

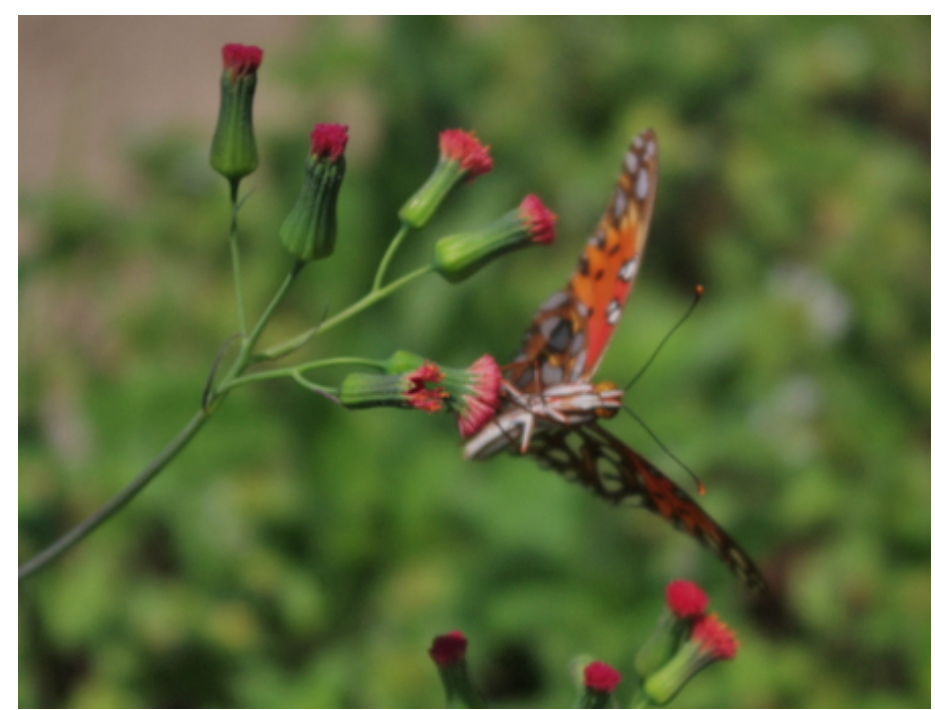

Figure 8. Emilia fosbergii flower attracting a butterfly.

Credits: Annette Chandler, UF/IFAS

\section{Management}

\section{Physical and Cultural Control}

Due to its high seed production and how easily weeds are spread by wind, tasselflower should be hand-weeded as soon as possible in nursery containers to prevent spread throughout the nursery. Nursery growers can prevent spread by having proper sanitation practices implemented throughout the nursery (using clean pots, using weedfree liners, keeping bark piles on concrete slabs, etc.). Tasselflower seed production is significantly reduced or eliminated if it is mowed frequently. Keeping walkways, aisles, and the area surrounding the nursery mowed can prevent spread into the crop. In the landscape, tasselflowers can be hand-weeded if they are growing in close proximity to ornamentals and can also be controlled by tilling prior to planting.

\section{Chemical Control \\ PREEMERGENCE TREATMENTS}

Tasselflowers are difficult to control with preemergence herbicides. In nurseries and landscapes, consistent control can be achieved with applications of indaziflam (Marengo ${ }^{\circledR}$ and Marengo ${ }^{\circledR} \mathrm{G}$ ) and flumioxazin (Broadstar ${ }^{\circledR}$ and SureGuard $^{\circledR}$ ) (Stamps et al. 1999; Stamps and Chandler 2013). Broadstar ${ }^{\circledR}$ and Marengo ${ }^{\circledR} \mathrm{G}$ are granular formulations and can be applied over the top of labeled ornamentals. Marengo ${ }^{\circledR}$ and SureGuard ${ }^{\circledR}$ cannot be applied over the top but can be applied as a directed application away from plant foliage and stems. In the landscape, it should be noted indaziflam is labeled as Specticle and Specticle G. Other preemergence herbicides that offer suppression of tasselflower include dimethenamid-P (Tower ${ }^{\circledR}$ and as a component of FreeHand ${ }^{\circledR}$ ) and oxyfluorfen combinations such as Biathlon, $\mathrm{OH} 2$, and others. A complete list of preemergence herbicides in which efficacy data is available for control of tasselflower is included in Table 1.

\section{POSTEMERGENCE TREATMENT}

Most broadleaf and nonselective herbicides labeled for use in nurseries and landscapes provide control of tasselflower. For larger plants, glyphosate may be the most effective option. In the landscape, clopyralid (Lontrel ${ }^{\circledR}$ ) is another option and can be applied over the top of certain ornamental plants listed on the label. Other herbicides such as glufosinate (Finale $\left.{ }^{\circledR}\right)$, diquat (Reward ${ }^{\circledR}$ ), pelargonic acid (Scythe ${ }^{\circledR}$ ), and other nonselective herbicides are also typically effective, but large plants or heavy infestations may require multiple applications because they are not translocated.

\section{References}

CAB International (CABI). 2019a. "Emilia fosbergii (Florida Tassel-flower)." https://www.cabi.org/isc/datasheet/114086

CAB International (CABI). 2019b. "Emilia sonchifolia (Red Tasselflower).” https://www.cabi.org/isc/datasheet/20833

Lessa, B. F. T., V. M. Ferreira, J. C. Neto, and R. C. Souza. 2013. "Germination of Emilia coccinea (Sims) G. Don as a Function of Light, Temperature, Storage, and Sowing Depth." Ciencias Agrarias 34 (6): 3193-3204. https://doi. org/10.5433/1679-0359.2013v34n6Supl1p3193

Neal, J. C., and J. F. Derr. 2005. Weeds of Container Nurseries in the United States. Raleigh, NC: North Carolina Assoc. of Nurserymen, Inc. 
Stamps, R. H., and A. L. Chandler. 1999. "Doveweed, Florida Tasselflower, and Eclipta Control under Heavy Rainfall Conditions Using Granular Preemergence Herbicides." Proceedings of the Southern Nurseryman's Association Research Conference 50:435-439.

Stamps, R. H., and A. L. Chandler. 2013. "Weed Control and Crop Safety Using Indaziflam around Established Landscape Shrubs." Proceedings of the Florida State Horticultural Society 126:257-259.

USDA-ARS. 2014a. "Germplasm Resources Information Network (GRIN). Plant Profile for Emilia fosbergii (Florida Tasselflower)." Accessed 31 March 2020. https://npgsweb. ars-grin.gov/gringlobal/taxonomydetail.aspx?id=104206

USDA-ARS. 2014b. “Germplasm Resources Information Network (GRIN). Plant Profile for Emilia sonchifolia (Red Tasselflower)." Accessed on 31 March 2020. https:// npgsweb.ars-grin.gov/gringlobal/taxonomydetail.

aspx?id=15124

Wunderlin, R. P., B. F. Hansen, A. R. Franck, and F. B. Essig. 2020. Atlas of Florida Plants. Accessed on 15 March 2020. http://florida.plantatlas.usf.edu/ 


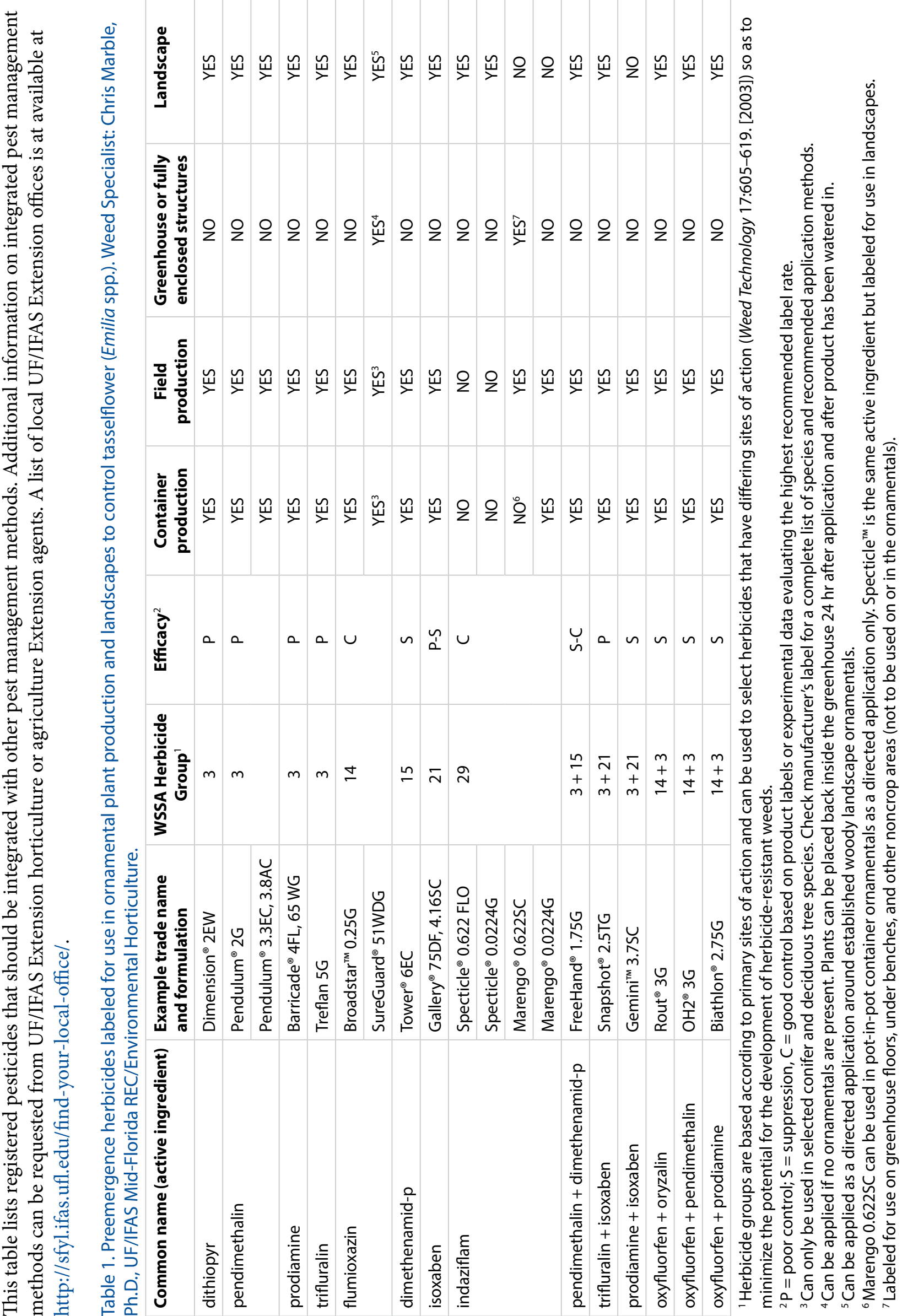

